\title{
Response of Two Varieties Productivity to Planting Methods and Weed Control under Sohag Governorate Conditions.
}

Hefny, Y.A.M. ${ }^{1}$; ${ }^{*}$ R.A. Dawood ${ }^{2}$; G.R. EL-Nagar ${ }^{2}$ and Anaam H. Galal ${ }^{2}$

${ }^{1}$ Agronomy Dep., Fac. Agric., Sohag Univ.

${ }^{2}$ Agronomy Dep., Fac. Agric., Assiut Univ. *Email: ragab.dawood@agr.au.edu.eg

\section{Abstract:}

Two field experiments were carried out in the Research Farm at AlKawthar, Faculty of Agriculture, Sohag University, in two successive seasons of 2010/2011 and 2011/2012 to study the response of Giza 168 and Sids 12 varieties to three planting methods (Afir broadcast, Afir drill and Afir in furrows) and four weed control trials (hand weeding twice at 30 and 45 days after sowing, Granstar $75 \% \mathrm{DF}$ at rate $8 \mathrm{~g} / \mathrm{fed}$. at 30 days after sowing, Topik $15 \% \mathrm{WP}$ at rate of 140 $\mathrm{g} / \mathrm{fed}$. at 40 days after sowing and Granstar $75 \% \mathrm{DF}$ at rate $8 \mathrm{~g} / \mathrm{fed}$. at 30 days after sowing + Topik 15\% WP at rate of $140 \mathrm{~g} / \mathrm{fed}$. at 40 days after sowing) on yield and yield components. A randomize complete block design (RCBD) in split-split plot with four replicates was used. Data indicated that the varieties, planting methods and weed control had significantly effect on the all studied traits; plant height $(\mathrm{cm})$, spike length $(\mathrm{cm})$, number of spikes $/ \mathrm{m}^{2}$, number of spikelets/spike, 1000-grain weight (g), grain yield (ardab/fed.) and biological yield (ton/fed.) in both seasons. Sids 12 variety produced the highest number of spikes $/ \mathrm{m}^{2}$, number of spikelets/spike, 1000-grain weight, grain yield and biological yield, but Giza 168 surpassed in plant height and spike length. Afir drill method increased significantly number of spikes $/ \mathrm{m}^{2}$, number of spikelets/spike, 1000-grain weight, grain yield (ardab/fed.) and biological yield (ton/fed.), as well as Afir broadcast and Afir in furrows methods increased plant height $(\mathrm{cm})$ and Spike length $(\mathrm{cm})$. The application of Granstar 75\% DF + Topik 15\% WP mixture increased spike length $(\mathrm{cm})$, number of spikes $/ \mathrm{m}^{2}$, number of spikelets/spike, 1000-grain weight (g), grain yield (ardab/fed.) and biological yield (ton/fed.). In general the highest grain yield (20.02 ardab/fed.) was obtained from the application of Granstar 75\% DF + Topik 15\% WP mixture under drill method.

Keywords: Broadcast, drill, weed control and biological yield.

Received on: $22 / 4 / 2015$

Referees: Prof. Elmahdy A. Teama
Accepted for publication on: 2/5/2015

Prof. Mansour A. Salem 


\section{Introduction:}

Wheat (Triticum aestivum L.) is an important cereal crops (Montazeri et al., 2005). Wheat occupy $17 \%$ of the world cultivated area and represents $35 \%$ of the staple food and $20 \%$ of diet calories (Chhokar et al., 2006). In Egypt, wheat is the main winter cereal crop and is widely distributed all over the country. The cultivated area ${ }^{*}$ is 3.35 million feddans in 2012/2013 season with an average grain yield of $18.5 \mathrm{ardab} / \mathrm{fed}$. Although, there was a good progress towards increasing the total wheat yield in Egypt in last years, still there is a big gab between the consumption and local production $(49.0 \% \%)$. The local production is about 9.3 million tons, while total consumption is 13.85 million tons in the 2013 season.

Weeds completion limit wheat yield potential in arid regions because they increase evapotranspiration and compete with wheat plants for limited soil moisture, water and light resulting in grain yield reduction amounted to $7 \%, 52 \%$ and $92 \%$, respectively (Khan et al., 2003 and Shah et al., 2005) and in serious cases may lead to complete crop failure (Zand et al., 2003 and Waheed et al., 2009). The effect of weeds on wheat yield has been reported by researchers worldwide. Zand et al. (2007) reported a 30 percent wheat yield loss and sometimes complete failure of the crop. There are many weed species compete with wheat. Shehzad et al. (2012) revealed that the diversity of Phalaris minor (P. minor) and Avena fatua (A. fatua) decreased ominously

*According to data of Statistical and Agricultural Economic Research Institute, Agric. Res. Center, Egypt, 2013. by all the herbicides compared to non-treated control. However, clodinafop propargyl at $60 \mathrm{~g}$ a.i $\mathrm{ha}^{-1}$ was found to be most effective as it severely reduced the weeds population as well as biomass with maximum mortality.

Currently, chemical weed control has emerged as an effective tool for weed management because it is approachable, less time consuming as well as economical (Baghestani et al., 2007). Naseer-ud-Din et al. (2011) suggested the post-emergence application of herbicides for increased yield and significant weed population reduction. On the other hand, weed resistance to herbicide application can pose problems in weed management (Beckie et al., 2000) and with the passage of time their evaluation should be performed (Baghestani et $a l ., 2007)$ and the introduction of new herbicides is a pre-requisite to eradicate the resistance of weeds.

Planting method plays an important role in the wheat plants competition with each other and with the weed species, which ultimately affects crop growth. The selection of suitable planting method for wheat is dependant upon the time of planting, availability of soil water at planting time, amount of residue in the field and availability of planting machine (Sikander et al., 2003). Abbas et al. (2009) revealed that the best plant height was obtained in drill planting with 30 and $22.5 \mathrm{~cm}$ rows. However, number of spikelets and number of grains/ spike were statistically similar in broadcasting and drilling at 22.5 $\mathrm{cm}$ apart rows. Similar 1000-grain weight was recorded in drill sowing at $30,22.5 \mathrm{~cm}$ and broadcasting. The 
maximum grain yield was obtained through broadcast method and it was statistically at par with drill planting method where row spacing was 22.5 $\mathrm{cm}$. Whereas, drill-planting techniques with row spacing $15 \mathrm{~cm}$ and $30 \mathrm{~cm}$ were inferior to broadcast method. It may be concluded that broadcast method is suitable for wheat sowing in sandy loam soils of arid area. Bashir et al. (2014) reported that the wheat sown by drilling method showed remarkably superior performance with 17.08 spikelets spike $^{-1}, 39.25$ grains spike ${ }^{-1}, 16.16 \mathrm{~g}$ grain weight spike ${ }^{-1}, 8653.40 \mathrm{~kg} \mathrm{ha}^{-1}$ biological yield and $4232.90 \mathrm{~kg} \mathrm{ha}^{-1}$ grain yield.

Use of highly competitive cultivars can be effective cultural practice for weed growth suppression (Wicks et al., 2004; Mennan and Zandstra, 2005). Mason et al. (2008) reported that the cultivars had early heading and maturity traits resulted in increase grain yield at the highest weed level. Abouziena et al. (2008) found that under the weed competition condition; Sids 9 cultivar produced the highest grain yield, while under unweeding treatment; Sids 7 cultivar gave the maximum yield. The rank order of competitive ability of the five wheat cultivars was Sids 9, Sakha 69, Sids 8, Sids 7 and Sids 6. Therefore, planting Sids 7 cultivar and controlling weeds by hand or tribenuron-methyl herbicide produced the highest yield.

\section{Materials and Methods:}

Two field experiments were carried out in the Research Farm at Al-
Kawthar, Faculty of Agriculture, Sohag University, in two successive seasons of 2010/2011 and 2011/2012 to investigate the effect of weed control and planting methods on wheat productivity. A randomize complete block design (RCBD) in split -split plot with four replications was used. The treatments were arranged as following: 1) four weed control treatments were arranged in the main plots: hand weeding twice (at 30 and 45 days after sowing), Granstar 75\% $\mathrm{DF}$ at rate $8 \mathrm{~g} / \mathrm{fed}$. at 30 days after sowing, Topik 15\% WP at rate of 140 $\mathrm{g} /$ fed. at 40 days after sowing and Granstar $75 \% \mathrm{DF}$ at rate $8 \mathrm{~g} / \mathrm{fed}$. at 30 days after sowing + Topik 15\% WP at rate of $140 \mathrm{~g} / \mathrm{fed}$. at 40 days after sowing. 2) three planting methods were placed in sub plot: Afir broadcast: Soil was plowed twice then grains were broadcasting and compacting was done and irrigation was followed, Afir drill: Soil was plowed twice then wheat grains were hand drilled in rows $20 \mathrm{~cm}$ apart rows and irrigation was followed and Afir in furrows method with $60 \mathrm{~cm}$ apart ridge Planting on double row sloping bed and the top of the ridge, 3) two varieties (Giza 168 and Sids 12) were fixed in sub-sub-plot, with plot area $10.5 \mathrm{~m}^{2}$ (3.5 m length $\times 3.0 \mathrm{~m}$ width).

Seeding rate was used as recommended (60 kg/fed.). Herbicides were sprayed by Cp3 knapsack sprayer with 200 litter of water/fed. Trade, common and chemical names of herbicides used in the experimental plots were presented in Table (1). 
Table (1): Trade, common and chemical names of the herbicides used in the experiment.

\begin{tabular}{|c|c|c|}
\hline \multicolumn{1}{|c|}{ Trade name } & $\begin{array}{c}\text { Common } \\
\text { name }\end{array}$ & \multicolumn{1}{c|}{ Chemical name } \\
\hline 1-Granstar75\% DF & $\begin{array}{c}\text { Tribenuron- } \\
\text { methyl }\end{array}$ & $\begin{array}{l}\text { [[[[N-(4-methoxy-6-methyl-1, 3, 5-triazin- 2-yl) } \\
\text { methylamino]carbonyl] amino] sulfonyl] }\end{array}$ \\
\hline 2- Topik 15\% WP & $\begin{array}{c}\text { Clodinafop } \\
\text { propargyl }\end{array}$ & $\begin{array}{l}\text { \{2propnil([-2-[4-(5-chloro-3- fluoro-2- pyrid- } \\
\text { nyloxy) phenoxy]-propionate }\}\end{array}$ \\
\hline
\end{tabular}

In this study, sowing date was on $29^{\text {th }}$ November and $1^{\text {st }}$ December in the first and second seasons, respectively. The preceding summer crop was maize (Zea mays L.) in both seasons.
Soil of the experiment was sandy-clay, mechanical and chemical properties of soil are shown in Table (2). The other agriculture practices were.

Table (2): Mechanical and chemical properties of top soil $(0-30 \mathrm{~cm})$ of the experimental site in 2010/2011 and 2011/2012 seasons.

\begin{tabular}{|l|l|l|}
\hline & \multicolumn{2}{|c|}{ Values } \\
\hline Soil Properties & $\mathbf{2 0 1 0 / 2 0 1 1}$ & $\mathbf{2 0 1 1 / 2 0 1 2}$ \\
\hline Mechanical analysis: & & \\
\hline Sand (\%) & 50.35 & 49.51 \\
\hline Silt (\%) & 18.72 & 19.40 \\
\hline Clay (\%) & 30.93 & 31.09 \\
\hline Soil texture & Sandy-clay & Sandy-clay \\
\hline Chemical analysis: & & \\
\hline Organic mater (\%) & 2.81 & 2.46 \\
\hline Total N (\%) & 0.153 & 0.181 \\
\hline pH (1:1) & 7.8 & 7.4 \\
\hline $\mathrm{Ec}_{(\mathrm{dS} / \mathrm{m}) 1: 5} 1.5$ & 0.7 \\
\hline $\mathrm{CaCO}_{3}$ & 0.5 & 11.2 \\
\hline
\end{tabular}

\section{Data recorded:}

At harvest: a sample of ten plants was randomly chosen from each plot in four replicates to measure: plant height, spike length, number of spikelets/spike, as well as number of spikes $/ \mathrm{m}^{2}$ and 1000 grain weight were recorded from one square meter. Biological and grain yields per feddan were recorded by weighing all above ground dry mater of each plot, then grain separating and weighing in kilograms and converted into ton and ard. per fed., respectively.
Statistical analysis:

The data were statistically analyzed each season separately by Proc GLM procedure (SAS version 9.1, SAS Institute 2003) as well as the least significant differences (LSD) among the factor means and their interactions at probability level at 5\% .

\section{Results and Discussion:}

Main effect:

Data presented in Table (3) revealed that the varieties, planting methods and weed control had significantly effect on the all studied traits, plant height $(\mathrm{cm})$, spike length 
(cm), number of spikes $/ \mathrm{m}^{2}$, number of spikelets/spike, 1000-grain weight (g), grain yield (ardab/fed.) and biological yield (ton/fed.) in both seasons.

\section{1- Effect of varieties:}

The results in Table 3 revealed that the tallest plants $(87.45$ and $88.92 \mathrm{~cm}$ ) were achieved by Giza 168 variety in the $1^{\text {st }}$ and $2^{\text {nd }}$ seasons, respectively. Moreover, the longest spikes $(10.14$ and $10.77 \mathrm{~cm})$ and the maximum values of number of spikes $/ \mathrm{m}^{2}$ (313.17 and 355.85), number of spikelets/spike $\quad(17.25$ and18.30), 1000-grain weight (41.97 and43.63 g), grain yield (15.24 and $16.25 \mathrm{ardab} / \mathrm{fed}$.) and biological yield (4.86 and 5.56 ton/fed) were exhibited by Sids 12 variety in the $1^{\text {st }}$ and $2^{\text {nd }}$ seasons, respectively. The results mean that the Sids 12 variety was the effective variety for achieving the maximum values of the all studied traits except the plant height. The difference between varieties could be attributed to the genetic make up. These results are in harmony with those studied by Abouziena et al. (2008) and Mason et al., (2008).

\section{2- Effect of planting methods:}

The results in Table 3 showed that the tallest plants $(87.50$ and $88.78 \mathrm{~cm}$ ) were obtained by Afir broadcast method, but the longest spikes $(10.32$ and $10.88 \mathrm{~cm})$ were resulted from Afir in furrows method in the $1^{\text {st }}$ and $2^{\text {nd }}$ seasons, respectively. Moreover, the maximum values of number of spikes $/ \mathrm{m}^{2} \quad$ (324.13, 366.00), number of spikelets/spike (17.91, 18.94), 1000-grain weight $(42.55$ and $44.23 \mathrm{~g})$, grain yield (15.92, $16.93 \mathrm{ardab} / \mathrm{fed}$.) and biological yield (4.92 and5.64 ton/fed.) were obtained by drill method in the $1^{\text {st }}$ and $2^{\text {nd }}$ seasons, respectively. Here, the results indicated to the drill method is the best planting methods, since it had superior over the other two planting methods (broadcast and in furrows). Partley (1980) noticed that broadcasting is generally inferior to placement of the seed in the soil, largely, because the conditions are less conductive to good germinations and establishment, with seedlings at greater risk of desiccation. The same conclusion was reported by Anaam (2003), Abd El-Hamid (2004), ElAfandy (2006), Seadh, and Badawi (2006), Ismail et al. (2008), Abbas et al.(2009) and Bashir et al.(2014).

\section{3- Effect of weed control:}

The results in Table 3 showed that the tallest plants were obtained by either Granstar $75 \%$ DF at rate 8 $\mathrm{g} /$ fed. at 30 days after sowing (87.58 and $89.67 \mathrm{~cm}$ ) or Topik $15 \% \mathrm{WP}$ at rate of $140 \mathrm{~g} / \mathrm{fed}$. at 40 days after sowing $(87.63$ and $88.96 \mathrm{~cm})$ in the $1^{\text {st }}$ and $2^{\text {nd }}$ seasons, respectively. Furthermore, the maximum values of spike length $(11.13$ and $11.65 \mathrm{~cm})$, number of spikes $/ \mathrm{m}^{2}$ (357.79 and 401.13), number of spikelets/spike (20.07 and 21.11), 1000-grain weight (44.02 and45.58 g), grain yield (17.95 and $18.94 \mathrm{ardab} /$ fed.) and biological yield (5.32 and 6.11ton/fed.) were achieved by Granstar $75 \%$ DF at rate $8 \mathrm{~g} / \mathrm{fed}$. at 30 days after sowing + Topik 15\% WP at rate of $140 \mathrm{~g} / \mathrm{fed}$. at 40 days after sowing in the $1^{\text {st }}$ and $2^{\text {nd }}$ seasons, respectively. Generally, the results indicated that application of the mixed of Granstar 75\% DF + Topik 15\% WP herbicides together, followed by the hand weeding treatments were the most effective in con- 
trolling weeds. Anaam (2003) stated that foliar application of Grasp at 1.0 L/fed., followed by hand weeding were more effective in controlling the most annual weeds as compared to the other treatments. These results are in conformity with those obtained by Omar and Aioub (2006), Younis (2007) and Shehzad et al. (2012).

\section{Interaction effect:}

\section{1- Varieties $x$ Planting methods (VxP) interaction:}

Data in Table 4 showed that all studied traits had a highly significantly affected by VxP interaction in both seasons ,except number of spikes $/ \mathrm{m}^{2}$ in both seasons, grain yield in the $1^{\text {st }}$ season and biological yield in the $2^{\text {nd }}$ season.

The results declared that the tallest plants $(89.01$ and $90.11 \mathrm{~cm})$ followed by $(87.98$ and $89.41 \mathrm{~cm}$ ) were acheaved by $\mathrm{V}_{1} \mathrm{xP}_{3}$ and $\mathrm{V}_{1} \mathrm{xP}_{1}$, as well as the longest spikes (10.51 and $11.11 \mathrm{~cm}$ ) were obtained by $\mathrm{V}_{2} \mathrm{XP}_{3}$ interaction treatments in the $1^{\text {st }}$ and $2^{\text {nd }}$ seasons, respectively. Moreover, the maximum values of number of spikes $/ \mathrm{m}^{2}$ (327.75 and 369.94) followed by (320.50 and 362.06), number of spikelets/spike (18.20 and $19.23)$ followed by (17.62 and 18.66), 1000 grain weight (42.91 and 44.53 g) followed by (42.20 and $43.93 \mathrm{~g})$, grain yield/fed. (16.15 and 17.15 ard.) followed by (15.70 and 16.71 ard.) and biological yield/fed. (4.95 and 5.76 ton) followed by (4.89 and 5.60 ton) were realysed by $\mathrm{V}_{2} \mathrm{xP}_{2}$ and $\mathrm{V}_{1} \mathrm{xP}_{2}$ in the $1^{\text {st }}$ and $2^{\text {nd }}$ seasons, respectively. On the other hand, the shortest plants and spikes (82.88 and $85.45 \mathrm{~cm})$ and $(8.99$ and $9.53 \mathrm{~cm})$ were obtained by $\mathrm{V}_{2} \mathrm{xP}_{3}$ and $\mathrm{V}_{1} \mathrm{xP}_{1}$ interaction treatments in the $1^{\text {st }}$ and $2^{\text {nd }}$ seasons, respectively. Likewise, the minimum values for the other studied traits were recorded by $\mathrm{V}_{1} \mathrm{xP}_{1}$ followed by $\mathrm{V}_{2} \mathrm{xP}_{1}$ interaction treatments in both seasons. This results mean that the Sids 12 variety under drill method gave the highest values, while the Giza 168 variety under broadcast method gave the lowest values. Hence, the results may be due to the genetic variation between varieties under various planting methods, reflect weather climatic conditions. Similar findings are stated by Soomro et al. (2009), Rahman et al. (2010) and Alam (2012).

\section{2-Varietis $\mathrm{x}$ weed control $(\mathrm{VxW})$ :}

Data in Table 4 showed that all studied traits had a highly significantly affected by $\mathrm{VxW}$ interaction in both seasons, except grain yield (ardeb/fed) in the $1^{\text {st }}$ season and biological yield in the $2^{\text {nd }}$ season.

The results showed that the tallest plants $(89.37$ and $89.41 \mathrm{~cm})$ followed by $(89.01$ and $90.11 \mathrm{~cm})$ were obtained by $\mathrm{V}_{1} \mathrm{xP}_{1}$ and $\mathrm{V}_{1} \mathrm{xP}_{3}$ interaction treatments in the $1^{\text {st }}$ and $2^{\text {nd }}$ seasons, respectively. Moreover, the maximum values for spike length $(11.39$ and $11.90 \mathrm{~cm})$ followed by $(10.87$ and $11.40 \mathrm{~cm})$, number of spikes $/ \mathrm{m}^{2}$ (361.75 and 405.00) followed by (353.83 and 397.25), number of spikelets/spike (20.40 and 21.46) followed by (19.47 and 20.77), 1000 grain weight (44.31 and 45.82 g) followed by (43.73 and $45.33 \mathrm{~g}$ ), grain yield/fed. (18.18 and 19.16 ard.) followed by (17.72 and 18.75 ard.) and biological yield/fed. (5.34 and 6.10 ton) followed by (5.30 and 6.12 ton) were recorded by $\mathrm{V}_{2} \mathrm{xW}_{4}$ and $\mathrm{V}_{1} \mathrm{xW}_{4}$ interaction treatments in the $1^{\text {st }}$ and $2^{\text {nd }}$ seasons, respectively. As 
well as, the shortest plants $(80.79$ and $82.84 \mathrm{~cm})$ were obtained by $\mathrm{V}_{2} \mathrm{xW}_{4}$ interaction treatment in the $1^{\text {st }}$ and $2^{\text {nd }}$ seasons, respectively. Likewise, the minimum values for the yield components and yield were recorded by $\mathrm{V}_{1} \mathrm{xW}_{2}$ interaction treatment in both seasons. The results suggested that the both varieties Sids 12 followed by Giza 168 under the mixed of the two herbicides either Granstar $75 \%$ DF or Topik 15\% WP gave reflection the highest values for the studied traits, since the effective factor may be due to specific weed control. These results are in harmony with those concluded by Mekky et al. (2007), Abouziena et al. (2008) and Sultana et al. (2012).

3- Planting methods $x$ weed control (PxW):

Data in Table 4 revealed that all studied traits had a highly significantly affected by PxW interaction in both seasons.

These results indicated that the tallest plants $(93.83 \mathrm{~cm})$ followed by $(92.93$ $\mathrm{cm})$ in the $1^{\text {st }}$ season, and $(94.97 \mathrm{~cm})$ followed by $(94.36 \mathrm{~cm})$ in the $2^{\text {nd }}$ season were showed by either $\mathrm{P}_{3} \times W_{3}$ followed by $\mathrm{P}_{2} \times W_{2}$ or by $\mathrm{P}_{2} \times W_{2}$ followed by $\mathrm{P}_{3} \times W_{3}$ interaction treatments, the longest spikes (11.84 and
$12.29 \mathrm{~cm})$ followed by (10.88 and $11.42 \mathrm{~cm}$ ) were obtained by $\mathrm{P}_{3} \mathrm{xW}_{4}$ followed by $\mathrm{P}_{2} \times W_{4}$ interaction treatments in the $1^{\text {st }}$ and $2^{\text {nd }}$ seasons, respectively. Moreover, the maximum values for number of spikes $/ \mathrm{m}^{2}$ (369.88 and 413.25) followed by (360.75 and 404.13), number of spikelets/spike (21.35 and 22.35) followed by (20.21 and 21.32), 1000 grain weight (45.20 and $46.70 \mathrm{~g}$ ) followed by (43.93 and $45.93 \mathrm{~g}$ ), grain yield/fed. (19.03 and 20.02 ard.) followed by (17.86 and 18.84 ard.) and biological yield/fed. (5.46 and 6.20 ton) followed by (5.33 and 6.22 ton) were realized by $\mathrm{P}_{2} \times W_{4}$ followed by $\mathrm{P}_{3} \mathrm{xW}_{4}$ interaction treatments in the $1^{\text {st }}$ and $2^{\text {nd }}$ seasons, respectively. On the other hand, the shortest plants $(80.96$ and $80.81 \mathrm{~cm})$ were obtained by $\mathrm{P}_{2} \times W_{2}$ interaction treatments. As well as, the minimum values for the other studied traits were recorded by $\mathrm{P} 1 \mathrm{xW} 4$ interaction treatments in both seasons. Here, the results realized that the drill method under mixed the two herbicides together gave the highest values. Similar findings are conformity by Anaam (2003), Younis (2007), Ismail et al. (2008) and Shehzad et al. (2012). 


\section{References:}

Abbas, G.; M.A. Ali; M. Azam and I. Hussain (2009). Impact of planting methods on wheat grain yield and yield contributing parameters. J. of Animal \& Plant Sciences 19(1): 30-33.

AbdEl-Hamid, M.M. (2004). Effect of sowing methods and weedcontrol treatments on wheat (Triticum aestivum L.) and associated weeds. J. Agric. Sci. Mansoura Univ., 29(8): 43914400.

Abouziena, H.F; A.A.S. Faida and E.R. El-Desoki (2008). Efficacy of cultivar selectivity and weed control treatments on wheat yield and associated weeds in sandy soils. World J. of Agric. Sci 4 (3): 384-389.

Alam, M.S. (2012). Effect of Sowing Patterns and Nitrogen Rates on Quality Traits and Yield of Wheat. J. Environ. Sci. \& Natural Resources, 5(1): 267-272.

Anaam, H. Galal (2003). Response of wheat and its associated weeds to sowing methods, seeding rates and weed control treatments. Assiut. J. Agric. Sci., 34(5): 77- 98.

Baghestani, M.A.; E. Zand; S. Soufizadeh; N. Bagherani and R. Deihimfard (2007). Weed control and wheat (Triticum aestivum L.) yield under application of 2,4-D plus carfentrazoneethyl and florasulam plus flumetsulam- Evaluation of the efficacy. Crop Protect. 26:17591764.

Bashir, W.; M.A. Ansari; A. Notani and F. Akber (2014). Influence of different sowing intervals and seedling methods on the germination, growth and yield of wheat variety T.D-1. Persian Gulf Crop Protection, 3(2): 3044.

Beckie, H.J.; I.M. Heap; R.J. Smeda and L.M. Hall (2000). Screening for herbicide resistance in weeds. Weed Technol. 14:428445.

Chhokar, R.S.; R.K. Sharma; D.S. Chauhan and A.D. Mongia (2006). Evaluation of herbicides against Phalaris minor in wheat in north-western Indian plains. Eur. Weed Res, 46:40-49.

El-Afandy, K.H.T. (2006). Effect of sowing methods and irrigation intervals on some wheat varieties grown under saline conditions at south Sinai. J. Agric Sci., Mansoura Univ., 31(2):573-586.

Ismail, A.E.A.; A.A.O. Fakkar and K.A. Hamam (2008). Effect of sowing methods and weed control treatments on yield and yield components of wheat. J. Agric. Sci., Mansoura Univ., 33(3):1799-1809.

Khan, M.H.; G. Hassan; N. Khan and M.A. Khan (2003). Efficacy of different herbicides for controlling broadleaf weeds in wheat. Asian J. P1. Sci., 2(3):254-256.

Mason, H.; L. Goonewardene and D. Spaner (2008). Competitive traits and the stability of wheat cultivars in differing natural weed environments on the Northern Canadian Prairies. The J. of Agric. Sci., 146:21-33.

Mekky, M.S.; M.A. Ali and S.A. Elmajeed (2007). Effect of mechanical tillage system, Wheat 
varieties and weed control treatments on weeds and wheat (Triticum aestivum L.) productivity. Misr J. Ag. Eng., 24(1): 18-41.

Mennan, H. and B. H. Zandstra (2005). Effect of wheat (Triticum aestivum $L$.) cultivars and seeding rate on yield loss from Galiumaparine (cleavers). Crop Protect. 24: 1061-1067.

Montazeri, M.; E. Zand and M.A. Baghestani (2005). Weeds and their control in wheat fields of Iran, first ed. Agric. Res. Edu.Org.

Naseer-ud-Din, G. M.; M. A. Shehzad and H. M. Nasrullah (2011). Efficacy of various pre and post-emergence herbicides to control weeds in wheat. Pak. J. Agric. Sci., 48:185-190.

Omar, A.E.A. and A.A.A. Aioub (2006). Efficiency of weed control methodson productivity of wheat under various moisture stress condition. Zagazig. J. Agric. Res., 33(1): 47-69.

Partley, J.E. (1980). Principles of field crop production. P. 289. Sydney University Press.

Rahman, M.A.; S.J. Hossain; M.B. Hossain; M.R. Amin and K.K. Sarkar (2010). Effect of variety and culture method on yield and yield attributes of wheat. Int. J. Sustain. Crop Prod. 5(3):17-21.

SAS Institute (2003). The SAS system for Windows, release 9.1. SAS Institute, Cary,N.C. USA

Seadh, S.E. and M.A. Badawi (2006). Wheat response to sowing methods and nitrogen fertilizer levels. J. Agric. Sci. Mansoura Univ., 8079 -8106.
Shah, N.H.; N.H. Ahmed and Inamullah (2005). Effect of different methods of weed control on the yield and yield components of wheat. Pak. J. Weed Sci. Res., 11(3-4): 97-101.

Shehzad, M.A.; M. Lqbal; A. Areeb and M. Arif (2012). Weed management and wheat (Triticum aestivum L.) yield under application of different postemergence herbicides. International.Res. J. of Agric Science and Soil Science. 2(4): 133-141.

Soomro, U.A.; M.U. Rahman; E.A. Odhano; S. Gul and A.Q. Tareen (2009). Effects of Sowing Method and Seed Rate on Growth and Yield of Wheat (Triticum aestivum). World J. of Agric. Sci., 5 (2): 159-162.

Sikander, K.T.; I. Hussain; M. Sohail; N.S. Kissana and S.G. Abbas (2003). Effect of different planting methods on yield and yield components of wheat. Asian J. Plant Sci., 2: 811-813.

Sultana, M.R.; M.A. Alim; M.B. Hossain; S. Karamaker and M.S. Islam (2012). Effect of variety and weed management practices on yield and yield attributes of wheat. J. Enoviron. Sci. \& Natural Resources, 5(2):91-96.

Waheed, A.; R. Qureshi; G.S. Jakhar and H. Tareen (2009). Weed community dynamics in wheat crop of District Rahim Yar Khan, Pakistan. Pak. J. Bot. 41:247-254.

Wicks, G.A.; P.T. Nordquist; P.S. Baenziger, R.N. Klein; R.H. Hammons and J.E. Watkins (2004). Winter wheat cultivar 
characteristics affect annual weed suppression. Weed Tech., 18: 988-998.

Younis, A.A.M. (2007). Response of durum wheat and associated weeds to some weed management under various seeding rates. M.Sc. Thesis, Fac. Agric, Minia Univ., Egypt.

Zand, E; M.A Baghestani; S. Soufizadeh; A. Eskandari; R.
PourAzar and M. Veysi (2007). Evaluation of some newly registered herbicides for weed control in wheat (Triticum aestivum L.) in Iran. Crop Protect.26:1349-1358.

Zand, E.; M.A. Baghestani and P. Shimi (2003). Weed control in wheat fields of Iran. Inter., Congress of Wheat, 419-450. 
استجابة و إنتاجيةصنفينمن القتح لطق الزراعةومقلومة الهثنث تتثظوف

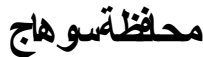

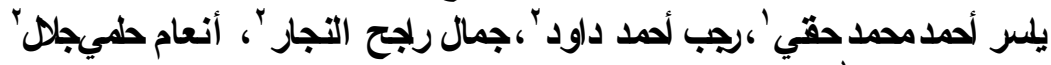

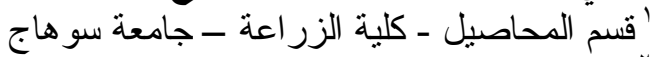

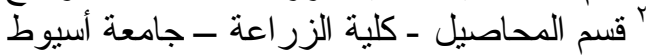

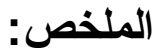

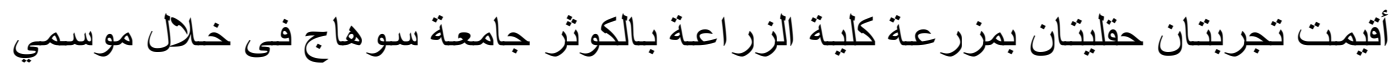

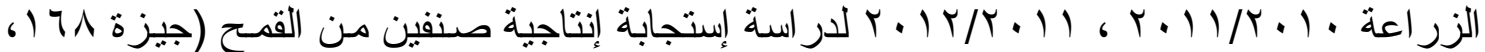

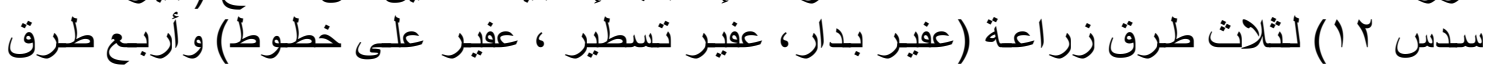

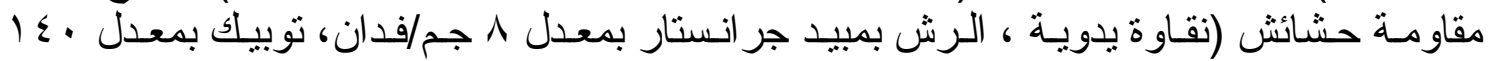

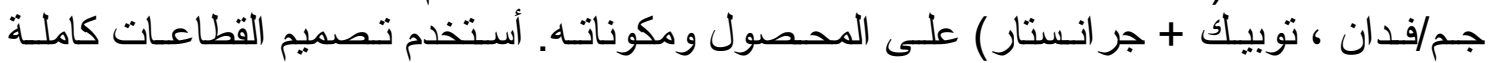

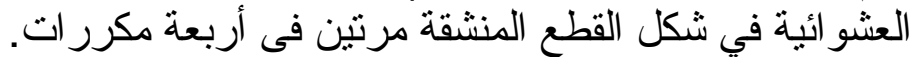

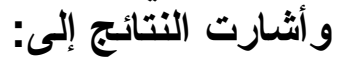

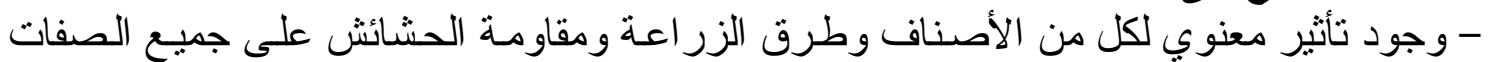

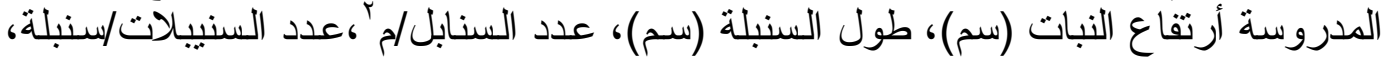

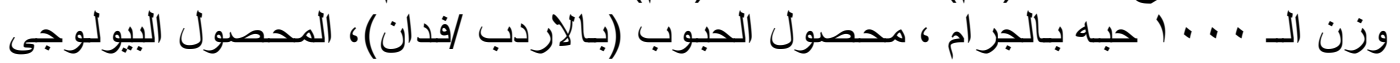

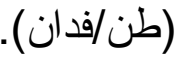

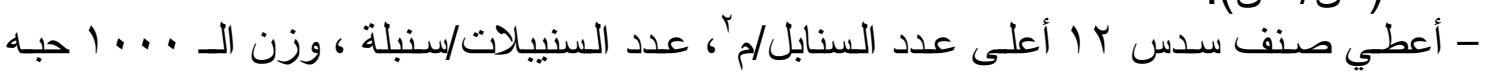

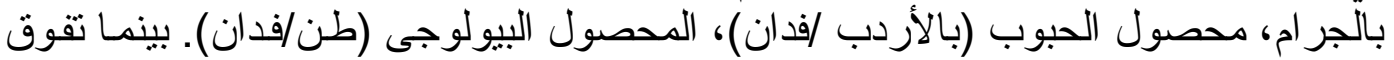

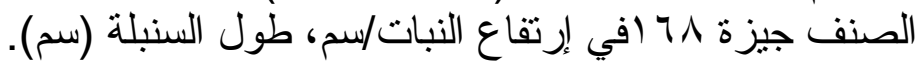

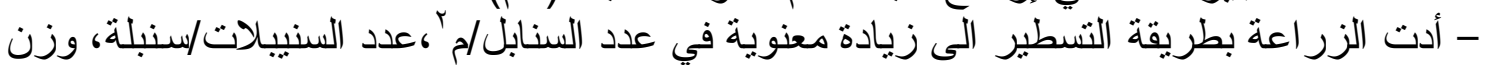

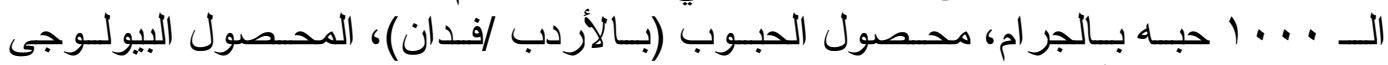

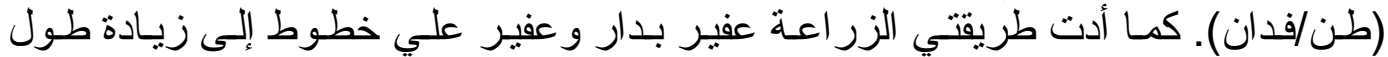
النبات (سم) ، طول السنبلة (سم) علي الثرنيب.

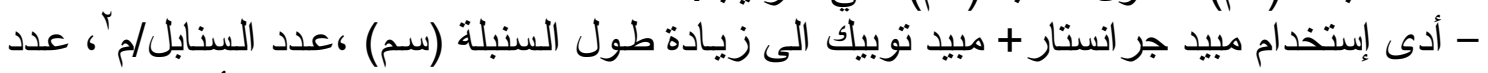

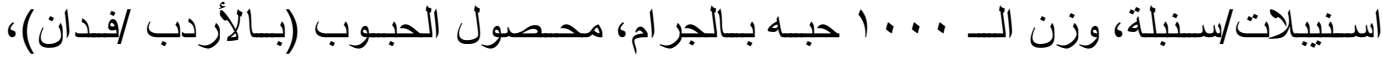
المحصول البيولوجى (طن/فدان).

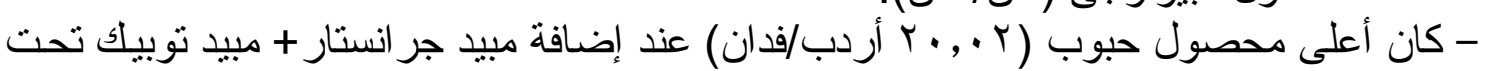
طريقة الزر اعة بالتسطير . 